\title{
Students' motivation and continued intention with online self-regulated learning: A self-determination theory perspective
}

\author{
Yumei Luo $\cdot$ Jinping Lin (D) $\cdot$ Yi Yang
}

Received: 8 June 2020 / Revised: 31 March 2021 / Accepted: 23 April 2021 / Published online: 30 August 2021

(C) The Editors of the Journal 2021

\begin{abstract}
Continued self-regulation is recognized as a critical factor for students' successful learning in an online learning environment. In the context of college students' online self-regulated learning (SRL), a research approach based on selfdetermination theory (SDT) is developed to explain the relations of students' basic psychological needs to their intrinsic and extrinsic motivation, as well as their continued intention to engage in online SRL. The results show that the three basic needs are associated with intrinsic motivation, while only two needs, namely perceived relatedness and competence, are related to extrinsic motivation. In addition, continued intention to engage in online SRL is related to intrinsic and extrinsic motivation. Our study provides empirical evidence for the appropriateness of the application of SDT in online SRL.
\end{abstract}

Keywords Online self-regulated learning $\cdot$ Self-determination theory $\cdot$ Continued intention

\footnotetext{
Yumei Luo · Yi Yang

College of Business and Tourism Management, Yunnan University, 2 North Road of Green

Lake, Kunming, Yunnan, China

E-Mail: luoyumei@ynu.edu.cn

Jinping Lin $(\bowtie)$

College of Resource Environment and Earth Science, Yunnan University, 2 North Road of Green

Lake, Kunming, Yunnan, China

E-Mail: linjp688@163.com
} 


\section{Motivation und Durchhaltevermögen bei der Selbstregulation im Online-Lernen: die Perspektive der Selbstbestimmungstheorie}

Zusammenfassung Fortgesetzte Selbstregulation gilt als entscheidend für den Lernerfolg in Online-Lernumgebungen. Auf der Grundlage der Selbstbestimmungstheorie (engl. SDT) wird daher ein Forschungsansatz entwickelt, der im Kontext des Online-Lernens von College-Studierenden die Zusammenhänge der in der SDT postulierten drei psychischen Grundbedürfnisse mit extrinsischer und intrinsischer Motivation erklärt sowie das Durchhaltevermögen, beim Online-Lernen Selbstregulationstechniken anzuwenden. Die Ergebnisse zeigen, dass die drei Grundbedürfnisse mit intrinsischer Motivation zusammenhängen, während nur zwei Bedürfnisse - Eingebundenheit und Kompetenz - mit extrinsischer Motivation in Zusammenhang stehen. Auch hängt das Durchhalten der Selbstregulation beim Online-Lernen mit extrinsischer sowie intrinsischer Motivation zusammen. Die Studie liefert empirische Evidenz dafür, dass die Selbstbestimmungstheorie sich produktiv auf das selbstregulierte Online-Lernen anwenden lässt.

Schlüsselwörter Selbstregulation und Online-Lernen · Selbstbestimmungstheorie · Durchhaltevermögen

\section{Introduction}

Compared with traditional learning environments, online learning environments provide learners with more fruitful and diverse learning resources and overcome the limits of time and space (Wang 2008), providing learners opportunities to perform self-regulated learning (SRL) (Azevedo and Cromley 2004; Greene and Azevedo 2009). SRL means that learners intentionally make an effort to manage and direct complicated learning activities (Kauffman 2004). Researchers have emphasized the importance of SRL, especially in an online learning context (Puzziferro 2008; Tsai 2011; Tsai et al. 2013; Wang 2011; Zheng 2016). According to Kauffman (2004), learners in an online learning environment must be highly self-regulated and independent; otherwise, their online learning effectiveness may be low (Carr 2000). In addition, the relatively high attrition and noncompletion rates have been reported and concerned (Bawa 2016; Boton and Gregory 2015).

Due to relying heavily on digital media and telecommunications, how to use these technologies is a key factor that is related to SRL effectiveness (Chang et al. 2017). From information technology use perspective, although online technologies bring flexible activities and rich learning resources for SRL (Chung 2015; Liaw 2008), the value of these technologies in learning will not be realized if students are unable to use them continually for learning (Bøe et al. 2015; Roca and Gagné 2008; Sørebø et al. 2009). Sørebø et al. (2009) said, "the nature of the technology enables students with new 'possibilities' not with 'ready to use' resources". In the information system (IS) research field, the success of an IS similar to an online learning system (e.g., improving learning effectiveness) eventually depends on its continued use rather than its first-time use (Bhattacherjee 2001). This notion is 
supported by previous research that shows that continued intention is associated with online learning success, fulfilling the meaning of "behavior of reuse" (Chiu et al. 2005; Roca et al. 2006; Roca and Gagné 2008). Accordingly, it is important to understand how to promote students' continued intention to engage in online SRL, which in turn contributes to the learning effectiveness.

Toward this end, we draw on self-determination theory (SDT), one of the wellknown motivation theories that has been applied in different domains and settings (Ryan and Deci 2020), to explain the relationships between students' basic psychological need, motivation, and continued intention. SDT emphasizes the importance of innate psychological needs, including autonomy, competence and relatedness, in driving people's motivation to perform activities (Deci and Ryan 2000). Although SDT has been widely applied to traditional face-to-face environments and proven to be a productive undertaking (Ryan and Deci 2020), it has been largely overlooked in the online learning context (Hsu 2019). Ryan and Deci (2020) suggested that future SDT research should look more closely at how technologies in e-learning and remote classrooms motivate student engagement and learning. SRL indeed requires students' self-motivated ability (Kuo et al. 2014). Therefore, SDT can help us understand how students form motivation, which is consequently associated with students' continued intention to utilize online technologies for SRL.

Although Roca and Gagné (2008) and Sørebø et al. (2009) have examined similar research questions of how the basic psychological needs are associated with online learners' motivation to continue using e-learning tools, the transferability of the findings with workers or teachers to college students might be limited. First, Roca and Gagné (2008) focused on the context of workplace. As learners, the differences between college students and workers are significant (Hodkinson 2005). For example, compared with college students, most of the learning of workers may arise directly out of workplace concerns and be more instrumental, of a lower academic level or ephemeral in nature (Lester and Costley 2010). Second, Sørebø et al. (2009) focused on the context of teaching and stressed that teachers and students hold different roles in an online learning environment; that is, teachers play a role as initiators, administrators, and facilitators of students' use of online learning, whereas students are mainly pure users. Consequently, the purpose of the present study is to extending the application of the SDT model into the college students' online SRL environment.

This study contributes to academic research and practice in various ways. First, it deepens the understanding of college students' continuance intention by providing an insight into various motivations and motivational triggers in online SRL context. Second, it shows the relation from various psychological needs to intrinsic and extrinsic motivation of students' online self-regulated learning. 


\section{Theoretical framework}

\subsection{Online self-regulated learning}

Online learning refers to one type of educational instruction with various online technologies, either completely asynchronous or partly synchronous learning, and with no appointed face-to-face time and location (Broadbent 2017). Self-regulating means controlling a process or activity by the individual who is involved in it, and this control includes a series of individual's cognitive activities and behaviors, i.e., observing, mastering and regulating (Garcia and Pintrich 1994). In autonomous online environments, it is up to students to decide when, where and how to learn; thus, students are responsible for their own learning (Wang et al. 2013), and self-regulation of learning becomes more important in an online context than in a traditional context (King et al. 2000; Wijekumar et al. 2006).

Self-regulated learners should have (meta)cognitive and (meta)motivational awareness of what they are doing and how they successfully attain self-set goals (Zimmerman 1990). Cognitive self-regulation is of concern to the regulation of learning process that includes a set of learning activities, such as orienting, planning, self-monitoring, self-evaluating, and repairing at various points during the process of acquisition (Zimmerman 1990). However, cognitive and metacognitive knowledge is usually not enough to promote student achievement; students must also be motivated to use the knowledge and regulate their cognition and effort (Pintrich and De Groot 1990). Motivational self-regulation considers the learning process as a whole and concerns the motivation of self-regulative behaviors, such as inclination, sensitivity, involvement degree and time, and effort level (Boekaerts 1996). In other words, the motivation essentially concerns students' reasons for doing a task and answers the question, "Why am I doing this task?". Self-regulated learning emphasizes that students are more effective when they take a purposeful role in their own learning. Students who have high motivational self-regulation report high self-efficacy, self-attributions and intrinsic task interest and display extraordinary effort and persistence during learning (Zimmerman 1990).

For the learners' continued intention to engage in online SRL, this paper mainly focuses on the motivational perception rather than the self-regulative cognitive process and suggests that self-regulated learners should hold a set of self-adaptive beliefs and attitudes to generate willingness to engage and persist in learning activities through using online technology. Specifically, these students with a motivational orientation involving goals of mastery, learning and challenge, as well as beliefs that the task is interesting and important, will engage in more metacognitive activities and more effective effort management techniques (Pintrich 2004). According to Pintrich (1999), learners can perform effective self-regulated learning only when they are highly motivated and persistent in their learning tasks.

\subsection{Self-determination theory (SDT)}

Self-determination theory (SDT) is a macro theory of motivation with six minitheories that explain different aspects of human motivation (Ryan and Deci 2019). 
For instance, cognitive evaluation theory (CET; Deci and Ryan 1980); organismic integration theory (OTI; Ryan et al. 1985); basic psychological needs (BPNT; Ryan et al. 1985); causality orientations theory (COT; Deci and Ryan 1985), goal content theory (GCT; Kasser and Ryan 1996), and relationship motivation theory (RMT; Deci et al. 2017). Over the years, these different mini-theories have been developed and refined through empirical investigation across different domains, cultures, and demographics. Moreover, Ryan and Deci (2019) suggest that the mini-theories are interrelated and can be systematically applied to explain motivational processes. For example, satisfaction of the three basic needs (BPNT theory) contributes to motivation to varying extents (OIT theory), which in turn drive people's behaviors. Therefore, we focus on BPNT and OIT in the current study.

SDT proposes that human beings have three fundamental psychological needs: autonomy, competence and relatedness (Deci and Ryan 2011; Ryan and Deci 2000). The need for autonomy refers to the feeling of choice and concurrence with one's actions; the need for competence refers to the feeling to be effective and capable; and the need for relatedness refers to the feeling of a connection to, caring for, and being cared for by other individuals and groups. Satisfaction of these basic needs are associated with high-quality motivation as well as well-being (Ryan 2019).

Another important concept entailed in SDT is a differentiated view of motivation (Deci and Ryan 2008; Olafsen et al. 2017). SDT highlights that different types of motivation relate to qualitatively different outcomes. In particular, there are two types of motivation, namely intrinsic motivation and extrinsic motivation. Intrinsic motivation pertains to activities done "for their own sake" or for their inherent interest and enjoyment (Ryan and Deci 2020). Individuals with intrinsic motivation enjoy the process of performing the activity (Deci and Ryan 1985; Vallerand 1997). Extrinsic motivation, on the other hand, concerns behavior done in order to attain some separable outcome other than their inherent satisfactions. Individuals with extrinsic motivation value results separable from a given activity itself (Ryan and Deci 2020).

We integrated the two sub-theories of BPNT and OIT to explain how and why satisfaction of the three basic psychological needs for autonomy, competence, and relatedness is essential for students' motivation and behaviors in the online SRL context.

\subsection{SDT in online SRL context}

As one of the earliest studies, Chen and Jang (2010) applied SDT to the online learning context and did not find a significant relationship between self-determined motivation and students' learning outcomes. Recently, Hsu (2019) examined the SDT-based model in online learning context and indicated that the satisfaction of basic psychological need enhanced self-regulated motivation and associated with higher perceived knowledge transfer and increased achievement of course objective in online course. Chiu (2021) investigated how the three perceived psychological needs in SDT affected student engagement in the K-12 online learning forced by the COVID-19 pandemic and found the needs were predictors of the level of engagement. Students' and teachers' motivation to use technology as a tool for learning is 
an active research area (Ryan and Deci 2020). However, college students' continued use in online SRL learning has yet to be examined from an SDT perspective.

From the perspective of technology use, only a handful of studies have examined the SDT-based model for online learners' motivation to continue using e-learning tools. For instance, Roca and Gagné (2008) extended technology acceptance model (TAM) by including the three psychological needs constructs from SDT to explain e-learning adoption in the workplaces. Sørebø et al. (2009) integrated SDT and the expectation-confirmation theory (ECT) to understand teachers' continuance behavior in e-learning use. The empirical evidences turned out to be inconsistent regarding the relationships between the basic psychological needs and motivation. Specifically, in a work setting, perceived relatedness positively associated with intrinsic motivation, but was not correlated with extrinsic motivation. In the teachers' context, perceived relatedness was not related to teachers' either intrinsic or extrinsic motivation. Perceived autonomy displayed not effects on extrinsic motivation for teachers, but showed to be significantly correlated with extrinsic motivation for workers. These results indicate that the relationships between the three basic needs and motivation vary across contexts, which calls for further examination of these relationships in our study context, that is, college students' online SRL.

Prior research on technology use also view intrinsically motivated individuals as enjoying the process of performing a given activity, and extrinsically motivated individuals as valuing the results rather than the process of performance (Deci and Ryan 2002; Li et al. 2013). In particular, most of the studies conceptualize perceived usefulness (PU) as the most important extrinsic motivator and perceived enjoyment (PE) as the most representative intrinsic motivator in the technology use context (e.g., Brown and Venkatesh 2005; Li et al. 2013; Davis et al. 1992). PU, which focuses on utilitarian considerations, refers to students' perceptions of whether using online SRL will help them perform academic tasks effectively and enhance their learning performance. The utilitarian view of human nature posits that positive consequences reinforce individuals' behaviors (Eisenberger and Cameron 1996). As such, it is plausible that in learning context, students would like to use online SRL if the enhanced learing perforamance derived from online SRL use can help them accrue learning-related benefits.

PE refers to the extent to which engaging in online SRL is perceived to be enjoyable in his/her own right. Admittedly, PE has typically been viewed as the representative intrinsic motivator in educational settings (Taylor et al. 2014) and repeatedly associated with a variety of positive outcomes, including long-term achievement (Froiland and Oros 2014), conceptual understanding (Vansteenkiste et al. 2008), less anxiety (Froiland 2011), voluntary persistence in educational tasks (Froiland 2015), lower high school dropout rates (Vallerand et al. 1997), classroom or behaviral engagement (Guthrie et al. 2007), as well as other aspects of academic success and psychological well-being (Ryan and Deci 2000). 


\section{Research model and hypotheses}

Our model based on SDT, depicted in Fig. 1, holds that perceived autonomy, perceived competence and perceived relatedness exert an important direct effect on PU (extrinsic motivation) and PE (intrinsic motivation), which in turn are important antecedents of continued intention of online SRL.

\subsection{Perceived autonomy}

A need for autonomy in students' own use of online learning means a desire to selfregulate their own choices and learning processes. A number of studies have shown the relationship between autonomy and positive outcomes. In the organizational context, Deci et al. (1989) found that support with autonomy has a significant impact on trust involving corporations and satisfaction. Gagné et al. (2000) demonstrated that management support fosters acceptance of organizational changes.

Indeed, several studies posited that autonomy promotes intrinsic and extrinsic motivation, which in turn produces positive outcomes. Williams and Deci (1996) showed that students present more internalization of the values in a course when they have more support with autonomy. In the IS domain, the perceived usefulness and perceived ease of the use of a system is affected by the perceived support from supervisors (Karahanna et al. 1999). In the context of e-learning, perceived autonomy predicts perceived usefulness and perceived playfulness (Roca and Gagné 2008). Perceived usefulness as a utility value belief in connection with the utilization of online learning is classified as extrinsic motivation by prior research (Lee et al. 2005; Venkatesh 1999). Perceived enjoyment as an enjoyable feeling in connection with the playfulness of online learning is regarded as intrinsic motivation (Venkatesh and Speier 2000).

In the present study, these notions imply that the degree of perceived autonomy in online learning is expected to be positively associated with both the perceived usefulness (extrinsic motivation) and perceived enjoyment (intrinsic motivation) of online SRL. Therefore, we hypothesize the following:

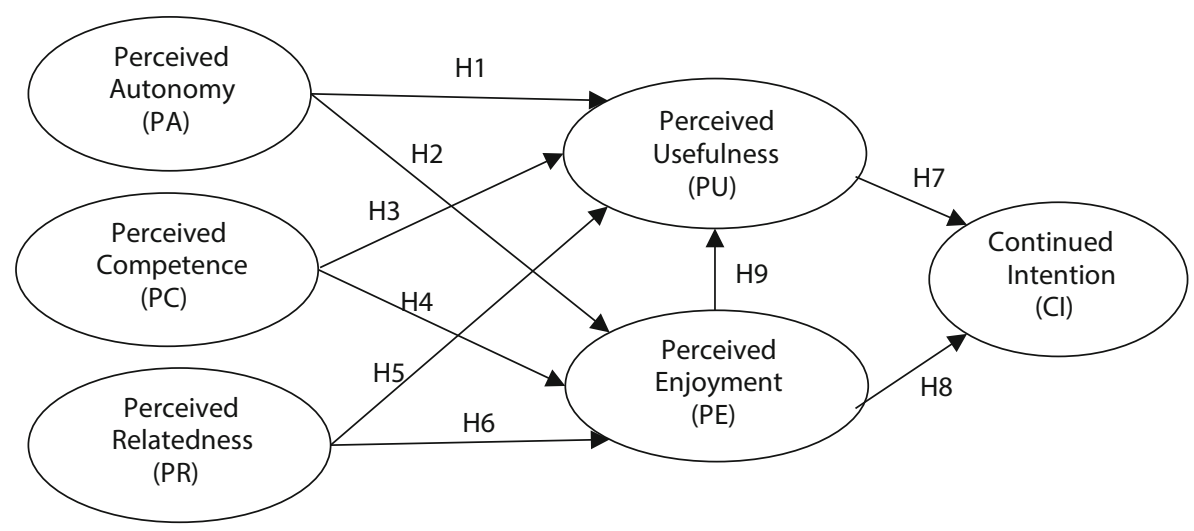

Fig. 1 Research model 
H1 Students' perceived level of autonomy when they utilize online learning is positively associated with their perceived level of usefulness.

H2 Students' perceived level of autonomy when they utilize online learning is positively associated with their perceived level of enjoyment.

\subsection{Perceived competence}

A need for competence during students' online learning reflects their desire to be effective in their utilization of the online tool to improve their academic performance. Deci and Ryan (1985) assumed that satisfying the need of competence influence the level of motivation. Students who are satisfied with online SRL competence will feel qualified to regulate their own engagement in online SRL. This feeling of being qualified is expected to be related with intrinsic and extrinsic motivation.

Competence is similar to the concept of self-efficacy (Roca and Gagné 2008), which refers to individuals' judgment of their capabilities to manage and execute activities to attain assigned performances (Bandura 1986, p. 391). In a social media context, Yang and Brown (2015) showed that the level of students' social competence links their perceived usefulness of social media. In the IS literature, computer competence has been shown to influence extrinsic motivation (i.e., perceived usefulness) (Compeau et al. 1999; Compeau and Higgins 1995; Rezvani et al. 2017) and intrinsic motivation (i.e., perceived enjoyment) (Roca and Gagné 2008). Sørebø et al. (2009) verified that the level of perceived competence in utilizing e-learning technology is associated with their perceived level of usefulness and enjoyment (Sørebø et al. 2009). We hypothesize:

H3 Students' perceived level of online self-regulated leaning competence is positively associated with their perceived level of usefulness.

H4 Students' perceived level of online self-regulated leaning competence is positively associated with their perceived level of enjoyment.

\subsection{Perceived relatedness}

A need for relatedness in students' online SRL reflects their desire to feel their activities connected with and supported by people close to them. According to SDT, individuals are likely to be more supportive of their group's goal when they feel connected to group members. Individuals still perform some uninterested or unenjoyable activities because they are valued by relevant others (e.g., peers, friends, family, superior or organization) (Deci and Ryan 2000). Therefore, satisfying their needs represents a type of social influence, which is similar to the concept of the subjective norm in the IS domain. Previous studies have demonstrated the influence of subjective norms on perceived usefulness and intrinsic motivation (e.g., perceived playfulness or perceived enjoyment) (Hsu and Chiu 2004; Roca and Gagné 2008; Sørebø et al. 2009; Venkatesh 2000). Regarding learning activity, Nikou and Economides (2017) found a positive relation among relatedness, usefulness and the ease 
of use of a learning activity. We argue that students' perceived relatedness with other important people is expected to influence usefulness and perceived enjoyment. Therefore, the following hypotheses are proposed:

H5 Students' perceived level of online self-regulated learning relatedness is positively associated with their perceived level of usefulness.

H6 Students' perceived level of online self-regulated learning relatedness is positively associated with their perceived level of enjoyment.

\subsection{Perceived usefulness}

The utilitarian view posits that positive consequences are useful to strengthen individuals' behaviors and involves the effects of extrinsic motivation on behaviors (Eisenberger and Cameron 1996). Perceived usefulness (PU) is assumed to create the instrumental behavior. Instrumental online SRL means engaging online SRL to increase students' learning performance, such as with rewards or scholarships. From a utilitarian perspective, PU has been considered one of the most representative constructs of extrinsic motivation for IS use. PU as the dominant determinant of continued IS use has been confirmed consistently over the past several decades (Bhattacherjee 2001; Hsieh and Wang 2007; Wang and Hsieh 2006). Here, the perceived utility values of online SRL are expected to affect students' intention for continued use. Therefore, we propose the following hypothesis:

H7 Students' level of perceived usefulness is positively associated with their level of intention to continue their use of online SRL.

\subsection{Perceived enjoyment}

Perceived enjoyment (PE) as intrinsic motivation has been consistent with empirical evidence showing a significant effect on intention for continued use (Lee 2010; Roca and Gagné 2008). Online learning provides students new and rich forms of learning, such as entertaining interactive functions, which make the activities more playful and enjoyable. Lee (2010) believed that users preferred to adopt a technology that brings fun and pleasure. Koufaris (2002) examined how shopping enjoyment is related to consumers' intention to return. Lin and Lu (2011) found that enjoyment has the most influence on the continued use of SNS. Joo et al. (2017) argued that enjoyment is associated with students' satisfaction and continued intention to use digital books. Therefore, if a student perceives the use of the online SRL as enjoyable, he or she is more likely to have a higher degree of intention to use online SRL. Thus,

H8 Students' level of perceived enjoyment is positively associated with their level of continued intention to use online SRL.

Many previous studies have agreed that PU is influenced by PE. Venkatesh (2000) and Poong et al. (2016) revealed that the indirect relationship between PU and PE through perceived ease of use. Li et al. (2005) argued that the relationship between 
PE and PU is direct and positive. Wang et al. (2012) supported that PE is related significantly to PU. Hence, we hypothesize the following:

H9 Students' level of perceived enjoyment is positively associated with their level of perceived usefulness.

\section{Research methodology}

\subsection{Measurement}

The items used to operationalize the variables in our research model were all adapted from existing studies with a few changes in wording to fit the context of online selfdetermined learning. Perceived usefulness and perceived enjoyment were measured using three-item scales adapted from Davis et al. (1992). The basic needs items (cf. perceived autonomy, perceived relatedness, and perceived competence) were adapted from Sørebø et al. (2009), and measured using three-, three- and fouritem scales, respectively. And two items of continued intention were adapted from Bhattacherjee (2001). All items were measured using seven-point Likert scales, ranging from "strongly disagree" (1) to "strongly agree" (7). A small-scale pretest of the questionnaire was conducted using 20 undergraduate students with online learning to assess questionnaire's logical consistency, comprehensible, sequence of items and contextual relevance. The items and their sources are listed in Table 4 in the Appendix.

\subsection{Data collection}

The research was conducted with undergraduates (sophomores and juniors) from a Chinese University that provides a MOOC platform including rich course. The students in the university can freely choose these courses in the MOOC platform to study and used online learning in the past because they had a required course in the first semester to learn how to use the Internet. The survey posted on the course message board and started on 15th September 2018 and lasted for half a month. The survey included three sections. In the first section, we briefly introduced the purpose of this study and ensures confidentiality. In the second section, we asked the participants to faithfully evaluate every questions in questionnaire. In the final section, the participants were asked to fill in demographic information, including gender, online time per day, and majors.

A total of 230 undergraduates filled out the questionnaire, of which three questionnaires left more than half of the questions unanswered and were dropped out, and the other 227 questionnaires has no missing data and were retained for data analysis. Of the 227 students, $40.1 \%$ respondents were male, almost $96 \%$ of students spent more than $2 \mathrm{~h}$ online a day, $52.8 \%$ majored in social science and humanities, and $41.2 \%$ majored in science and technology. 


\subsection{Results}

We used partial least squares (PLS), a component-based structural equation modeling technique, for data analysis. Chin and Newsted (1999) stated that PLS allows latent constructs to be modeled as formative or reflective indicators and issues minimal restrictions on the measurement scales, sample size, and residual distribution. We used SmartPLS 3.0 as the analytical software (Ringle et al. 2005) to evaluate the research model and then tested the hypotheses.

\subsubsection{Psychometric properties}

Tables 1 and 2 summarize psychometric properties of all constructs in our research model. Reliability was examined using the composite reliability (CR) and Cronbach's $\alpha$. Table 1 shows that the CR and Cronbach's $\alpha$ for all constructs in the measurement model exceeded the acceptable threshold of 0.7 (Fornell and Larcker 1981). Convergent validity was assessed by two criteria (Fornell and Larcker 1981). As shown in Table 1, all items exhibit a loading higher than the threshold of 0.7 on their respective constructs, and all of the AVEs ranged from 0.62 to 0.79 over 0.50 , thus satisfying both conditions for convergent validity.

Discriminant validity was tested using the following two tests. First, the loading of each item on its assigned construct is larger than its loadings on all other constructs (Table 1). Second, the square root of AVE for each construct exceeded all correlations

Table 1 Composite Reliability, Cronbach's $\alpha$, AVE and Cross Loading

\begin{tabular}{|c|c|c|c|c|c|c|c|c|c|c|}
\hline Constructs & CR & Cronbach's $\alpha$ & AVE & No & PA & PR & $\mathrm{PC}$ & $\mathrm{PU}$ & PE & $\mathrm{CI}$ \\
\hline \multirow{3}{*}{$\begin{array}{l}\text { Perceived } \\
\text { Auton- } \\
\text { omy (PA) }\end{array}$} & \multirow[t]{3}{*}{0.835} & \multirow[t]{3}{*}{0.704} & \multirow[t]{3}{*}{0.628} & PA1 & 0.800 & 0.307 & 0.605 & 0.499 & 0.483 & 0.393 \\
\hline & & & & PA2 & 0.814 & 0.333 & 0.466 & 0.418 & 0.465 & 0.279 \\
\hline & & & & PA3 & 0.763 & 0.497 & 0.484 & 0.456 & 0.546 & 0.399 \\
\hline \multirow{3}{*}{$\begin{array}{l}\text { Perceived } \\
\text { Related } \\
\text { (PR) }\end{array}$} & \multirow[t]{3}{*}{0.865} & \multirow[t]{3}{*}{0.766} & \multirow[t]{3}{*}{0.682} & PR1 & 0.412 & 0.879 & 0.403 & 0.491 & 0.520 & 0.459 \\
\hline & & & & PR2 & 0.395 & 0.751 & 0.274 & 0.408 & 0.397 & 0.350 \\
\hline & & & & PR3 & 0.391 & 0.842 & 0.321 & 0.456 & 0.512 & 0.498 \\
\hline \multirow{4}{*}{$\begin{array}{l}\text { Perceived } \\
\text { Compe- } \\
\text { tence } \\
\text { (PC) }\end{array}$} & \multirow[t]{4}{*}{0.893} & \multirow[t]{4}{*}{0.839} & \multirow[t]{4}{*}{0.675} & PC1 & 0.615 & 0.329 & 0.857 & 0.558 & 0.581 & 0.440 \\
\hline & & & & $\mathrm{PC} 2$ & 0.579 & 0.260 & 0.784 & 0.474 & 0.503 & 0.444 \\
\hline & & & & PC3 & 0.465 & 0.335 & 0.831 & 0.549 & 0.526 & 0.537 \\
\hline & & & & PC4 & 0.501 & 0.413 & 0.813 & 0.500 & 0.497 & 0.503 \\
\hline \multirow{3}{*}{$\begin{array}{l}\text { Perceived } \\
\text { Useful- } \\
\text { ness (PU) }\end{array}$} & \multirow[t]{3}{*}{0.887} & \multirow[t]{3}{*}{0.809} & \multirow[t]{3}{*}{0.723} & PU1 & 0.472 & 0.540 & 0.526 & 0.841 & 0.610 & 0.588 \\
\hline & & & & PU2 & 0.502 & 0.410 & 0.539 & 0.853 & 0.591 & 0.524 \\
\hline & & & & PU3 & 0.507 & 0.445 & 0.555 & 0.858 & 0.639 & 0.576 \\
\hline \multirow{3}{*}{$\begin{array}{l}\text { Perceived } \\
\text { Enjoy- } \\
\text { ment (PE) }\end{array}$} & \multirow[t]{3}{*}{0.851} & \multirow[t]{3}{*}{0.737} & \multirow[t]{3}{*}{0.656} & PE1 & 0.521 & 0.512 & 0.498 & 0.546 & 0.829 & 0.603 \\
\hline & & & & PE2 & 0.553 & 0.428 & 0.554 & 0.585 & 0.796 & 0.498 \\
\hline & & & & PE3 & 0.459 & 0.469 & 0.509 & 0.623 & 0.804 & 0.566 \\
\hline \multirow{2}{*}{$\begin{array}{l}\text { Continued } \\
\text { Intention } \\
\text { (CI) }\end{array}$} & \multirow[t]{2}{*}{0.884} & \multirow[t]{2}{*}{0.738} & \multirow[t]{2}{*}{0.792} & CI1 & 0.412 & 0.508 & 0.548 & 0.586 & 0.613 & 0.890 \\
\hline & & & & $\mathrm{CI} 2$ & 0.398 & 0.439 & 0.492 & 0.593 & 0.609 & 0.891 \\
\hline
\end{tabular}


Table 2 Correlations among variables and square root of average variance extracted

\begin{tabular}{lllllllll}
\hline Constructs & Mean & S.D. & PA & PR & PC & PU & PE & CI \\
\hline PA & 4.264 & 1.053 & $\mathbf{0 . 7 9 2}$ & - & - & - & - & - \\
PR & 4.226 & 0.978 & 0.482 & $\mathbf{0 . 8 2 6}$ & - & - & - & - \\
PC & 4.441 & 1.156 & 0.657 & 0.407 & $\mathbf{0 . 8 2 2}$ & - & - & - \\
PU & 4.717 & 1.117 & 0.580 & 0.548 & 0.635 & $\mathbf{0 . 8 5 1}$ & - & - \\
PE & 4.565 & 1.009 & 0.631 & 0.581 & 0.642 & 0.722 & $\mathbf{0 . 8 1 0}$ & - \\
CI & 4.736 & 1.161 & 0.455 & 0.532 & 0.584 & 0.662 & 0.687 & $\mathbf{0 . 8 9 0}$ \\
\hline
\end{tabular}

Diagonal elements are the square root of Average Variance Extracted

$P A$ perceived autonomy, $P R$ Perceived relatedness, $P C$ Perceived competence, $P U$ Perceived usefulness, $P E$ Perceived enjoyment, $C I$ Continued intention

between the construct and other constructs in the model (Fornell and Larcker 1981). As shown in Table 2, we concluded that the discriminant validity was confirmed.

The above evidence suggests acceptable psychometric properties for all constructs in our research model.

Hypotheses tests This study verified the structural hypotheses of the proposed model by analyzing the structural estimates produced by PLS. A standard bootstrapping procedure (Yung and Bentler 1996) with 1000 re-samples comprising identical number of cases in the original sample was applied to determine the significance of each estimated path coefficient. Fig. 2 shows the results of the structural path analysis. Standardized regression coefficients are shown above each path, and the $\mathrm{R}$-squared is shown with each endogenous variable.

As shown in Fig. 2, the direct relation from perceived autonomy to perceived usefulness was not significant $(\beta=0.069$, ns), with $\mathrm{H} 1$ unsupported. Perceived autonomy was positively related to perceived enjoyment $(\beta=0.247, p<0.001)$, supporting $\mathrm{H} 2$. As expected, perceived competence was positively related to perceived usefulness and perceived enjoyment $(\beta=0.252, p<0.01 ; \beta=0.350, p<0.001$, respectively), supporting $\mathrm{H} 3$ and H4. Perceived relatedness was positively associated with perceived

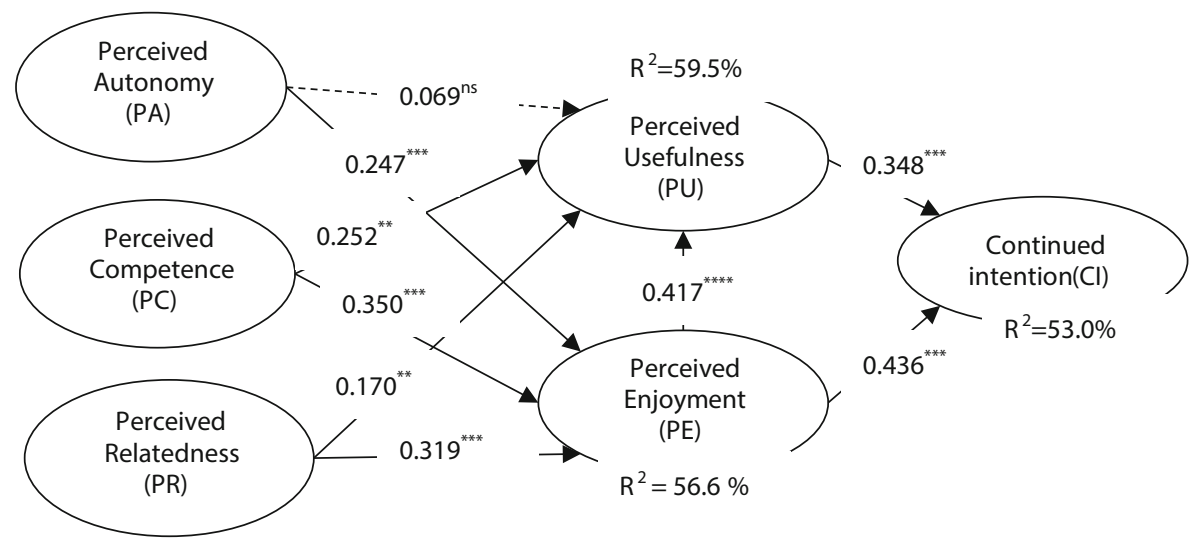

Fig. 2 Structural model PLS results. ( $n s$ non-significant. $* p<0.05$, $* * p<0.01$, $* * * p<0.001$ ) 
Table 3 The Sobel test results

\begin{tabular}{lllll}
\hline Mediator & Dependent variables & Independent variables & t-Value & Results \\
\hline Perceived & Continued intention & Perceived Competence & 2.278 & Supported \\
Usefulness & & Perceived Relatedness & 1.942 & Partially supported \\
Perceived & \multirow{2}{*}{ Continued intention } & Perceived Autonomy & 2.595 & Supported \\
Enjoyment & & Perceived Competence & 3.042 & Supported \\
& & Perceived Relatedness & 3.187 & Supported \\
& \multirow{2}{*}{ Perceived Usefulness } & Perceived Autonomy & 3.068 & Supported \\
\hline
\end{tabular}

usefulness $(\beta=0.170, p<0.05)$ and perceived enjoyment $(\beta=0.319, p<0.001), \mathrm{H} 5$ and $\mathrm{H} 6$ supported.

In support of $\mathrm{H} 7$, perceived usefulness was associated with continued intention of online SRL $(\beta=0.348, p<0.001)$. Perceived enjoyment was associated with continued intention of online SRL $(\beta=0.436, p<0.001)$ and perceived usefulness ( $\beta=0.417, p<0.001$ ), supporting $\mathrm{H} 8$ and $\mathrm{H} 9$, respectively.

We further examined the mediation roles of perceived usefulness and perceived enjoyment by using Sobel test (Sobel 1982). As shown in Table 3, the results showed the indirect relations from the three basic psychological needs to continued intention through perceived usefulness and perceived enjoyment. In particular, the indirect relationships between perceived competence and perceived relatedness and continued intention through perceived usefulness were significant; the indirect association between the three basic psychological needs and continued intention through perceived enjoyment was significant; and the indirect link between perceived autonomy and perceived usefulness through perceived enjoyment was significant.

As Fig. 2 shows, the research model explained 53\% of the variance for the intention to continue using online SRL, 59.5\% of the variance for perceived usefulness, and $56.6 \%$ of the variance for perceived enjoyment.

\section{Discussion and implementation}

The present study explores the role of perceived autonomy, perceived competence and perceived relatedness in explaining the influence of intrinsic and extrinsic motivation on the continued intention to engage in online SRL. Intrinsic and extrinsic motivations are operationalized using the constructs of perceived enjoyment and perceived usefulness, respectively.

Our findings suggest that SDT is favorable for understanding the influence of organizational factors in student's motivation for online SRL. It appears that students are more willing to continue using online technologies for learning when they feel autonomous, competent and related, because the satisfaction of these basic needs are related to their intrinsic and extrinsic motivation, which in turn associated with their intention to continue using online SRL.

Perceived autonomy is associated with perceived enjoyment ( $\mathrm{H} 2$ is supported) but not with perceived usefulness (H1 is not supported). The finding is similar to the result in teacher's utilization of e-learning, but not consistent with the result in 
workplace context. Due to focusing on the self-regulation, the students are known for their relatively high general study-autonomy and autonomy in connection with online platform usage may therefore be taken for granted. The opposite may be true for worker in workplace, since they may be controlled more, and thus, probably more important for perceived support of autonomy. The finding also indicates that students who are unpressured to engage in online learning are likely to experience a high level of enjoyment. In a climate of supportive autonomy, students are more likely to be intrinsically motivated to use the online technology for SRL.

Interestingly, among the three basic psychological needs, perceived competence of online SRL seems to be the most important influence on intrinsic motivation (H3) and extrinsic motivation (H4). This difference is somewhat surprising because SDT asserts that autonomy is essential to users' intrinsic and extrinsic motivation (Roca and Gagné 2008). This finding confirms that competence has a stronger relationship with motivation for online SRL. First, high self-regulation for learning is known as the nature of SRL, and therefore, autonomy may be taken for granted. Second, competence may be a scarce resource in the academic context and probably becomes more important for the development of intrinsic and extrinsic motivation (Sørebø et al. 2009).

The third basic need, perceived relatedness, is correlated with perceived usefulness (H5) and perceived enjoyment (H6). It is inconsistent with the results in the context of teachers' (Sørebø et al. 2009) and general worker' utilization of e-learning technology (Roca and Gagné 2008). The association between perceived relatedness and perceived enjoyment is stronger than its relationship with perceived usefulness. This outcome suggests that students are more likely to be intrinsically motivated to use the system in a climate of relatedness. Consistent with past studies, Ryan and La Guardia (2000) found that intrinsic motivation was more likely to grow in a related climate, and Deci and Ryan (2000) suggested that individuals should have more interest in performing behaviors that are valued by others close to them. Therefore, it is essential that students feel connected to other significant members if they are to be willing to continue using online SRL.

The indirect relationships between the three basic needs, including perceived autonomy, perceived competence, and perceived relatedness, and continued intention are all significant. Therefore, our findings are in line with prior studies in the SDT domain. For instance, Baard et al. (2004) and Deci et al. (2001) empirically showed that the satisfied degree of the three basic needs in their work organizations is useful to predict task engagement.

Perceived usefulness (H7) and perceived enjoyment (H8) are significant associated with the continued intention to engage in online SRL, and perceived enjoyment is more related to continued intention than did perceived usefulness. It is interesting that in the SRL context, students' willingness for online learning depends more on intrinsic motivation. This outcome confirms that intrinsic motivation is superior in self-regulated situations.

Our results clearly indicate that perceived enjoyment is related to perceived usefulness (H9) (Ong et al. 2004; Ong and Lai 2006; Taylor and Todd 1995). This outcome suggests that when users enjoy using the online technology to learn, they also perceive that these technologies will make them more productive. Additionally, 
a number of studies showed that people experienced more interest, excitement and confidence, which in turn also improved their performance, persistence and creativity (Deci and Ryan 1991).

In conclusion, the findings of this research contribute both to the literature and to practice. In online self-regulation learning context, our study demonstates the importance of students' perceived autonomy, competence and relatedness of online SRL in relation to their development of extrinsic and intrinsic motivation.

From a managerial point of view, one of the major implications is that educational organizations should promote perceptions of autonomy, competence and relatedness among their students to increase a continued intention to engage in online SRL because students will show greater interest and better performance. Second, individuals show more engagement when they participate in an activity or task because of interesting and enjoyable activities. Therefore, programmers and developers should build learning systems with friendly screens, interesting content and game-based learning to improve students' experiences of pleasure and enjoyment, which in turn result in higher perceived usefulness and higher continued intention of online SRL. Furthermore, some activities, such as regular meetings, cooperation, and sharing information among students and teachers, could improve students' perceived usefulness and enjoyment. Finally, organizations should establish a set of training and achievable goals and give constructive feedback to increase students' perceived competence.

\section{Conclusion}

The goal of the present study is based on SDT to explain the role of intrinsic and extrinsic motivation in continued intention to engage in online SRL. The direct relation from intrinsic and extrinsic motivation to continued intention, from perceived autonomy, competence and relatedness to intrinsic motivation and extrinsic motivation, are examined. To achieve the study objective, a theory model is empirically tested by 227 undergraduates who enrolled in online learning.

The results of examining the model show that intrinsic and extrinsic motivation are significantly associated with students' continued intention to engage in online SRL, and intrinsic motivation is more associated with students' continued intention than extrinsic motivation. Intrinsic motivation is related directly and significantly to perceived autonomy, competence and relatedness. Furthermore, extrinsic motivation is associated significantly and directly with perceived competence and relatedness, as well as indirectly with perceived autonomy through intrinsic motivation. Finally, intrinsic motivation is related significantly to extrinsic motivation.

Although there are implications above, there are some limitations as follows. The sample of the study is limited to undergraduates. Some studies found that learners' educational level, age and gender were related to online learning (Wang et al. 2009). Adopting online self-regulated learning for trainees has become more popular and important for their job performance. Therefore, exploring the study in many different contexts would be valuable in the future. In addition, based on SDT, extrinsic motivation has been specified four major subtypes, such as external, 
introjected, identified and integrated regulation (Ryan and Deci 2020). Therefore, it provides the opportunity to explore the influence of different extrinsic motivation on continued intention.

\section{Appendix}

Table 4 Survey items

\begin{tabular}{|c|c|c|c|}
\hline Constructs & No. & Items & Refs. \\
\hline \multirow{3}{*}{$\begin{array}{l}\text { Perceived } \\
\text { Autonomy } \\
\text { (PA) }\end{array}$} & PA1 & $\begin{array}{l}\text { I feel like I can make a lot of inputs to decide how I use online } \\
\text { technology in my self-regulated learning }\end{array}$ & \multirow{3}{*}{$\begin{array}{l}\text { Søreb } \varnothing \\
\text { et al. } \\
(2009)\end{array}$} \\
\hline & PA2 & $\begin{array}{l}\text { There is a lot of opportunity for me to decide for myself how } \\
\text { to use online technology in my self-regulated learning }\end{array}$ & \\
\hline & PA3 & $\begin{array}{l}\text { I can make my own decisions about online self-regulated } \\
\text { learning }\end{array}$ & \\
\hline \multirow{3}{*}{$\begin{array}{l}\text { Perceived } \\
\text { Related } \\
(\mathrm{PR})\end{array}$} & PR1 & I get along with my teacher at online self-regulated learning & \multirow{3}{*}{$\begin{array}{l}\text { Søreb } \varnothing \\
\text { et al. } \\
\text { (2009) }\end{array}$} \\
\hline & PR2 & I get along with my classmates in self-regulated learning & \\
\hline & PR3 & My friends at online self-regulated learning support me & \\
\hline \multirow{4}{*}{$\begin{array}{l}\text { Perceived } \\
\text { Compe- } \\
\text { tence (PC) }\end{array}$} & PC1 & I feel confident in finding the learning material online & \multirow{4}{*}{$\begin{array}{l}\text { Sørebø } \\
\text { et al. } \\
(2009)\end{array}$} \\
\hline & $\mathrm{PC} 2$ & I am good at online technology in my self-regulated learning & \\
\hline & PC3 & $\begin{array}{l}\text { I think that I have the capability to find learning material on- } \\
\text { line }\end{array}$ & \\
\hline & PC4 & $\begin{array}{l}\text { I feel very competent when I use online technology in my self- } \\
\text { regulated learning }\end{array}$ & \\
\hline \multirow{3}{*}{$\begin{array}{l}\text { Perceived } \\
\text { Usefulness } \\
\text { (PU) }\end{array}$} & PU1 & $\begin{array}{l}\text { Using online self-regulated learning improves my study per- } \\
\text { formance }\end{array}$ & \multirow{3}{*}{$\begin{array}{l}\text { Davis } \\
\text { et al. } \\
(1992)\end{array}$} \\
\hline & PU2 & Using online self-regulated learning increases my knowledge & \\
\hline & PU3 & $\begin{array}{l}\text { Overall, I find online self-regulated learning useful to my } \\
\text { studying }\end{array}$ & \\
\hline \multirow{3}{*}{$\begin{array}{l}\text { Perceived } \\
\text { Enjoyment } \\
\text { (PE) }\end{array}$} & PE1 & I find using online self-regulated learning to be enjoyable & \multirow{3}{*}{$\begin{array}{l}\text { Davis } \\
\text { et al. } \\
(1992)\end{array}$} \\
\hline & PE2 & $\begin{array}{l}\text { The actual process of using online self-regulated learning is } \\
\text { pleasant }\end{array}$ & \\
\hline & PE3 & I have fun using online self-regulated learning & \\
\hline \multirow{2}{*}{$\begin{array}{l}\text { Intention to } \\
\text { Continue } \\
\text { (IC) }\end{array}$} & IC1 & $\begin{array}{l}\text { I intend to continue using online self-regulated learning in the } \\
\text { future }\end{array}$ & \multirow{2}{*}{$\begin{array}{l}\text { Bhatta- } \\
\text { cherjee } \\
(2001)\end{array}$} \\
\hline & IC2 & $\begin{array}{l}\text { I expect my use of online self-regulated learning to continue in } \\
\text { the future }\end{array}$ & \\
\hline
\end{tabular}


Funding This research was supported by the National Natural Science Foundation of China (71402159, 41561031).

\section{References}

Azevedo, R., \& Cromley, J. G. (2004). The role of self-regulated learning in fostering students' understanding of complex systems with hypermedia. Journal of Educational Computing Research, 30(1-2), 87-111.

Baard, P.P., Deci, E.L., \& Ryan, R. M. (2004). Intrinsic need satisfaction: a motivational basis of performance and Weil-being in two work settings. Journal of Applied Social Psychology, 34(10), 2045-2068.

Bandura, A. (1986). Social foundations of though and action. Englewood Cliffs: Prentice-Hall.

Bawa, P. (2016). Retention in online courses: exploring issues and solutions-a literature review. SAGE Open, 6(1), 1-11.

Bhattacherjee, A. (2001). Understanding information systems continuance: an expectation-confirmation model. MIS Quarterly, 25(3), 351-370.

Bøe, T., Gulbrandsen, B., \& Sørebø, Ø. (2015). How to stimulate the continued use of ICT in higher education: Integrating Information Systems Continuance Theory and agency theory. Computers in Human Behavior, 50(9), 375-384.

Boekaerts, M. (1996). Self-regulated learning at the junction of cognition and motivation. European Psychologist, 1(2), 100-112.

Boton, E.C., \& Gregory, S. (2015). Minimizing attrition in Online degree courses. Journal of Educators Online, 12(1), 62-90.

Broadbent, J. (2017). Comparing online and blended learner's self-regulated learning strategies and academic performance. Internet \& Higher Education, 33(2), 24-32.

Brown, S. A., \& Venkatesh, V. (2005). Model of adoption of technology in households: a baseline model test and extension incorporating household life cycle. MIS Quarterly, 29(3), 399-426.

Carr, S. (2000). As distance education comes of age, the challenge is keeping the students. Chronicle of Higher Education, 46(23), A39-A41.

Chang, C. T., Hajiyev, J., \& Su, C. R. (2017). Examining the students' behavioral intention to use e-learning in Azerbaijan? The general extended technology acceptance model for E-learning approach. Computers \& Education, 111, 128-143.

Chen, K.C., \& Jang, S.J. (2010). Motivation in online learning: testing a model of self-determination theory. Computers in Human Behavior, 26(4), 741-752.

Chin, W.W., \& Newsted, P.R. (1999). Structural equation modeling analysis with small samples using partial least squares. In R. Horyle (Ed.), Statistical strategies for small sample research (pp. 307-342). Thousand Oaks: SAGE.

Chiu, C. M., Hsu, M.H., Sun, S. Y., Lin, T. C., \& Sun, P.C. (2005). Usability, quality, value and e-learning continuance decisions. Computers \& Education, 45(4), 399-416.

Chiu, T. (2021). Applying the self-determination theory (SDT) to explain student engagement in Online learning during the pandemic. Journal of Research on Technology in Education, 1-17, https://doi.org/ 10.1080/15391523.2021.1891998.

Chung, L. Y. (2015). Exploring the effectiveness of self-regulated learning in massive open online courses on non-native English speakers. International Journal of Distance Education Technologies, 13(3), 61-73.

Compeau, D.R., \& Higgins, C.A. (1995). Computer self-efficacy: development of a measure and initial test. MIS Quarterly, 19(2), 189-211.

Compeau, D., Higgins, C. A., \& Huff, S. (1999). Social cognitive theory and individual reactions to computing technology: a longitudinal study. MIS Quarterly, 23(2), 145-158.

Davis, F. D., Bagozzi, R.P., \& Warshaw, P. R. (1992). Extrinsic and intrinsic motivation to use computers in the workplace. Journal of Applied Social Psychology, 22(14), 1111-1132.

Deci, E.L., \& Ryan, R.M. (1980). Self-determination theory: when mind mediates behavior. Journal of Mind \& Behavior, 1(1), 33-43.

Deci, E., \& Ryan, R. M. (1985). Intrinsic motivation and self-determination in human behavior. New York: Plenum Press.

Deci, E. L., \& Ryan, R. M. (1991). A motivational approach to self: Integration in personality. In R. Dienstbier (Ed.), Nebraska symposium on motivation: Perspectives on motivation (Vol. 38, pp. 237-288). Lincoln: University of Nebraska Press. 
Deci, E.L., \& Ryan, R.M. (2000). The "what" and "why" of goal pursuits: human needs and the selfdetermination of behavior. Psychological Inquiry, 11(4), 227-268.

Deci, E.L., \& Ryan, R.M. (2002). Handbook of self-determination. Rochester: Research University of Rochester Press.

Deci, E. L., \& Ryan, R. M. (2008). Self-determination theory: a macrotheory of human motivation, development, and health. Canadian Psychology, 49(3), 182-185.

Deci, E. L., \& Ryan, R. M. (2011). Levels of analysis, regnant causes of behavior and wellbeing: the role of psychological needs. Psychological Inquiry, 22(1), 17-22. https://doi.org/10.1080/1047840x.2011. 545978.

Deci, E.L., Connell, J.P., \& Ryan, R.M. (1989). Self-determination in a work organization. Journal of Applied Psychology, 74(4), 580-590.

Deci, E.L., Olafsen, A.H., \& Ryan, R.M. (2017). Self-determination theory in work organizations: the state of a science. Annual Review of Organizational Psychology and Organizational Behavior, 4(1), 19-43.

Deci, E. L., Ryan, R. M., Gagné, M., Leone, D. R., Usunov, J., \& Kornazheva, B. P. (2001). Need satisfaction, motivation, and well-being in the work organizations of a former eastern bloc country: a crosscultural study of self-determination. Personality and Social Psychology Bulletin, 27(8), 930-942.

Eisenberger, R., \& Cameron, J. (1996). Detrimental effects of reward: reality or myth? American Psychologist, 51(11), 1153-1166.

Fornell, C., \& Larcker, D.F. (1981). Evaluating structural equation models with unobservable variables and measurement error. Journal of Marketing Research, 18(1), 39-50.

Froiland, J. M. (2011). Parental autonomy support and student learning goals: a preliminary examination of an intrinsic motivation intervention. Child and Youth Care Forum, 40(2), 135-149.

Froiland, J. M. (2015). Parents' weekly descriptions of autonomy supportive communication: promoting children's motivation to learn and positive emotions. Journal of Child and Family Studies, 24(1), $117-126$.

Froiland, J. M., \& Oros, E. (2014). Intrinsic motivation, perceived competence and classroom engagement as longitudinal predictors of adolescent reading achievement. Educational Psychology, 34(2), 119-132.

Gagné, M., Koestner, R., \& Zuckerman, M. (2000). Facilitating acceptance of organizational change: the importance of self-determination. Journal of Applied Social Psychology, 30(9), 1843-1852.

Garcia, T., \& Pintrich, P.R. (1994). Regulating motivation and cognition in the classroom: The role selfschemas and self-regulatory strategies. In D.H. Schunk \& B. J. Zimmerman (Eds.), Self-regulation of learning and performance: issues and educational applications (pp. 127-153). Hillsdale: Lawrence Erlbaum.

Greene, J. A., \& Azevedo, R. (2009). A macro-level analysis of SRL processes and their relations to the acquisition of a sophisticated mental model of a complex system. Contemporary Educational Psychology, 34(1), 18-29.

Guthrie, J. T., Mcrae, A., \& Klauda, S. L. (2007). Contributions of concept-oriented reading instruction to knowledge about interventions for motivations in reading. Educational Psychologist, 42(4), 237-250.

Hodkinson, P. (2005). Reconceptualising the relations between college-based and workplace learning. Journal of Workplace Learning, 17(8), 521-532.

Hsieh, J., \& Wang, W. (2007). Explaining employees' Extended Use of complex information systems. European Journal of Information Systems, 16(3), 216-227.

Hsu, M.-H., \& Chiu, C.-M. (2004). Internet self-efficacy and electronic service acceptance. Decision Support Systems, 38(3), 369-381. https://doi.org/10.1016/j.dss.2003.08.001.

Hsu, H. C. K., Wang, C. V., \& Levesque-Bristol, C. (2019). Reexamining the impact of self-determination theory on learning outcomes in the online learning environment. Education and information technologies, 24(3), 2159-2174.

Joo, Y.J., Park, S., \& Shin, E. K. (2017). Students' expectation, satisfaction, and continuance intention to use digital textbooks. Computers in Human Behavior, 69(4), 83-90.

Karahanna, E., Straub, D. W., \& Chervany, N.L. (1999). Information technology adoption across time: a cross-sectional comparison of pre-adoption and post-adoption beliefs. MIS Quarterly, 23(2), $183-213$.

Kasser, T., \& Ryan, R. M. (1996). Further examining the American dream: differential correlates of intrinsic and extrinsic goals. Personality \& Social Psychology Bulletin, 22(3), 280-287.

Kauffman, D.F. (2004). Self-regulated learning in web-based environments: Instructional tools designed to facilitate cognitive strategy use, metacognitive processing, and motivational beliefs. Journal of Educational Computing Research, 30(1-2), 139-161. 
King, F. B., Harner, M., \& Brown, S. W. (2000). Self-regulatory behavior influences in distance learning. International Journal of Instructional Media, 27(2), 147-155.

Koufaris, M. (2002). Applying the technology acceptance model and flow theory to online consumer behavior. Information Systems Research, 13(2), 205-223.

Kuo, Y.-C., Walker, A.E., Schroder, K.E.E., \& Belland, B.R. (2014). Interaction, Internet self-efficacy, and self-regulated learning as predictors of student satisfaction in online education courses. Internet \& Higher Education, 20, 35-50. https://doi.org/10.1016/j.iheduc.2013.10.001.

Lee, M.-C. (2010). Explaining and predicting users' continuance intention toward e-learning: an extension of the expectation-confirmation model. Computers \& Education, 54(2), 506-516. https://doi.org/10. 1016/j.compedu.2009.09.002.

Lee, M. K. O., Cheung, C.M. K., \& Chen, Z. (2005). Acceptance of Internet-based learning medium: the role of extrinsic and intrinsic motivation. Information \& Management, 42(8), 1095-1104.

Lester, S., \& Costley, C. (2010). Work-based learning at higher education level: value, practice and critique. Studies in Higher Education, 35(5), 561-575.

Li, D., Chau, P. Y. K., \& Lou, H. (2005). Understanding individual adoption of instant messaging: an empirical investigation. Journal of the Association for Information Systems, 6(4), 102-129.

Li, X., Hsieh, J.J.P.-A., \& Rai, A. (2013). Motivational differences across post-acceptance information system usage behaviors: an investigation in the business intelligence systems context. Information Systems Research, 24(3), 659-682. https://doi.org/10.1287/isre.1120.0456.

Liaw, S. S. (2008). Investigating students' perceived satisfaction, behavioral intention, and effectiveness of e-learning: A case study of the Blackboard system. Computers \& Education, 51(2), 864-873.

Lin, K. Y., \& Lu, H.P. (2011). Why people use social networking sites: an empirical study integrating network externalities and motivation theory. Computers in Human Behavior, 27(3), 1152-1161.

Nikou, S. A., \& Economides, A. A. (2017). Mobile-based assessment: integrating acceptance and motivational factors into a combined model of self-determination theory and technology acceptance. Computers \& Education, 68(6), 83-95.

Olafsen, A.H., Deci, E. L., \& Halvari, H. (2017). Basic psychological needs and work motivation: a longitudinal test of directionality. Motivation \& Emotion, (2), 1-12. https://doi.org/10.1007/s11031-0179646-2.

Ong, C.S., \& Lai, J. Y. (2006). Gender differences in perceptions and relationships among dominants of e-learning acceptance. Computers in Human Behavior, 22(5), 816-829.

Ong, C.S., Lai, J.Y., \& Wang, Y.S. (2004). Factors affecting engineers' acceptance of asynchronous e-learning systems in high-tech companies. Information \& Management, 41(6), 795-804.

Pintrich, P. R. (1999). The role of motivation in promoting and sustaining self-regulated learning. International Journal of Educational Research, 31(6), 459-470.

Pintrich, P.R. (2004). A conceptual framework for assessing motivation and self-regulated learning in college students. Educational Psychology Review, 16(4), 385-407.

Pintrich, P.R., \& De Groot, E. V. (1990). Motivational and self-regulated learning components of classroom academic performance. Journal of Educational Psychology, 82(1), 33-40.

Poong, Y. S., Yamaguchi, S., \& Takada, J. I. (2016). Investigating the drivers of mobile learning acceptance among young adults in the World Heritage town of Luang Prabang, Laos. Information Development, $33(1), 57-71$.

Puzziferro, M. (2008). Online technologies self-efficacy and self-regulated learning as predictors of final grade and satisfaction in college-level online courses. American Journal of Distance Education, 22(2), 72-89.

Rezvani, A., Khosravi, P., \& Dong, L. (2017). Motivating users toward continued usage of information systems: self-determination theory perspective. Computers in Human Behavior, 76(11), 263-275. https://doi.org/10.1016/j.chb.2017.07.032.

Ringle, C. M., Wende, S., \& Will, A. (2005). SmartPLS 2.0 (M3) beta. http://www.smartpls.de

Roca, J.C., \& Gagné, M. (2008). Understanding e-learning continuance intention in the workplace: a selfdetermination theory perspective. Computers in Human Behavior, 24(4), 1585-1604. https://doi.org/ 10.1016/j.chb.2007.06.001.

Roca, J.C., Chiu, C. M., \& Martínez, F. J. (2006). Understanding e-learning continuance intention: an extension of the Technology Acceptance Model. International Journal of Human-Computer Studies, 64(8), 683-696.

Ryan, R.M., \& Deci, E.L. (2000). Self-determination theory and the facilitation of intrinsic motivation, social development, and well-being. The American Psychologist, 55(1), 68-78. https://doi.org/10. 1037/0003-066x.55.1.68. 
Ryan, R. M., \& Deci, E.L. (2019). Chapter four-brick by brick: the origins, development, and future of self-determination theory. In A. J. Elliot (Ed.), Advances in motivation science (Vol. 6, pp. 111-156). Amsterdam: Elsevier.

Ryan, R. M., \& La Guardia, J.G. (2000). What is being optimized over development? A self-determination theory perspective on basic psychological needs across the life span. In S. Qualls \& R. Abeles (Eds.), Dialogues on psychology and aging (pp. 145-172). Washington, DC: American Psychological Association.

Ryan, R. M., Connell, J.P., \& Deci, E.L. (1985). A motivational analysis of selfdetermination and selfregulation in education (Research on motivation in education: The classroom milieu). New York: Academic Press.

Ryan, R. M., Ryan, W. S., Di Domenico, S. I., \& Deci, E. L. (2019). The nature and the conditions of human autonomy and flourishing: Self-determination theory and basic psychological needs In R. M. Ryan (Ed.), The Oxford handbook of human motivation (2nd ed.] (pp. 89-110). New York: NY: Oxford University Press.

Ryan, R. M., \& Deci, E.L. (2020). Intrinsic and extrinsic motivation from a self-determination theory perspective: definitions, theory, practices, and future directions. Contemporary Educational Psychology, https://doi.org/10.1016/j.cedpsych.2019.101831.

Sobel, M.E. (1982). Asymptotic confidence intervals for indirect effects in structural equation models. Sociological Methodology, 13, 290-312. https://doi.org/10.2307/270723.

Sørebø, Ø., Halvari, H., Gulli, V.F., \& Kristiansen, R. (2009). The role of self-determination theory in explaining teachers' motivation to continue to use e-learning technology. Computers \& Education, 53(4), 1177-1187. https://doi.org/10.1016/j.compedu.2009.06.001.

Taylor, S., \& Todd, P. (1995). Assessing IT usage: the role of prior experience. MIS Quarterly, 19(4), $561-570$.

Taylor, G., Jungert, T., Mageau, G. A., Schattke, K., Dedic, H., \& Rosenfield, S. (2014). A self-determination theory approach to predicting school achievement over time: the unique role of intrinsic motivation. Contemporary Educational Psychology, 39(4), 342-358. https://doi.org/10.1016/j.cedpsych. 2014.08.002.

Tsai, C.W. (2011). Achieving effective learning effects in the blended course: a combined approach of online self-regulated learning and collaborative learning with initiation. Cyberpsychology Behavior \& Social Networking, 14(9), 505-510.

Tsai, C. W., Shen, P. D., \& Fan, Y.T. (2013). Research trends in self-regulated learning research in online learning environments: a review of studies published in selected journals from 2003 to 2012. British Journal of Educational Technology, 44(5), E107-E110.

Vallerand, R. J. (1997). Toward A hierarchical model of intrinsic and extrinsic motivation. Advances in experimental social psychology, 29(8), 271-360.

Vallerand, R. J., Fortier, M.S., \& Guay, F. (1997). Self-determination and persistence in a real-life setting: toward a motivational model of high school dropout. Journal of Personality and Social Psychology, 72(5), 1161-1176.

Vansteenkiste, M., Timmermans, T., Lens, W., Soenens, B., \& Van den Broeck, A. (2008). Does extrinsic goal framing enhance extrinsic goal-oriented individuals' learning and performance? An experimental test of the match perspective versus self-determination theory. Journal of Educational Psychology, $100,387-397$.

Venkatesh, V. (1999). Creation of favorable user perceptions: exploring the role of intrinsic motivation. MIS Quarterly, 23(2), 239-260.

Venkatesh, V. (2000). Determinants of perceived ease of use: integrating control, intrinsic motivation, and emotion into the technology acceptance model. Information Systems Research, 11(4), 342-365.

Venkatesh, V., \& Speier, C. (2000). Creating an effective training environment for enhancing telework. International Journal of Human-Computer Studies, 52(6), 991-1005.

Wang, T.H. (2008). Web-based quiz-game-like formative assessment: development and evaluation. Computers \& Education, 51(3), 1247-1263.

Wang, T.H. (2011). Developing Web-based assessment strategies for facilitating junior high school students to perform self-regulated learning in an e-Learning environment. Computers \& Education, 57(2), 1801-1812. https://doi.org/10.1016/j.compedu.2011.01.003.

Wang, W., \& Hsieh, P.A. (2006). Beyond routine: symbolic adoption, extended use, and emergent use of complex information systems in the mandatory organizational context. Paper presented at the Proceeding of the 27th International Conference on Information Systems, Milwaukee. 
Wang, C.-H., Shannon, D. M., \& Ross, M.E. (2013). Students' characteristics, self-regulated learning, technology self-efficacy, and course outcomes in online learning. Distance Education, 34(3), 302-323. https://doi.org/10.1080/01587919.2013.835779.

Wang, W., Ngai, E.W.T., \& Wei, H. (2012). Explaining instant messaging continuance intention: the role of personality. International Journal of Human-Computer Interaction, 28(8), 500-510.

Wang, Y.S., Wu, M.C., \& Wang, H. Y. (2009). Investigating the determinants and age and gender differences in the acceptance of mobile learning. British Journal of Educational Technology, 40(1), 92-118.

Wijekumar, K., Ferguson, L., \& Wagoner, D. (2006). Problems with assessment validity and reliability in web-based distance learning environments and solutions. Journal of Educational Multimedia \& Hypermedia, 15(2), 199-215.

Williams, G.C., \& Deci, E.L. (1996). Internalization of biopsychosocial values by medical students: a test of self-determination theory. Journal of Personality and Social Psychology, 70(4), 767-779.

Yang, C.-C., \& Brown, B.B. (2015). Factors involved in associations between Facebook use and college adjustment: social competence, perceived usefulness, and use patterns. Computers in Human Behavior, 46(3), 245-253. https://doi.org/10.1016/j.chb.2015.01.015.

Yung, Y.F., \& Bentler, P. M. (1996). Bootstrapping techniques in analysis of mean and covariance structures. In G. A. Marcoulides \& R. E. Schumacker (Eds.), Advanced structural equation modeling: Issues and techniques (pp. 195-226). London: Psychology Press.

Zheng, L. (2016). The effectiveness of self-regulated learning scaffolds on academic performance in computer-based learning environments: a meta-analysis. Asia Pacific Education Review, 17(2), 187-202. https://doi.org/10.1007/s12564-016-9426-9.

Zimmerman, B.J. (1990). Self-regulated learning and academic achievement: an overview. Educational Psychologist, 25(1), 3-17. 